\title{
HEADACHES IN ADOLESCENTS - FREQUENCY, RISK FACTORS AND OTHER HEALTH COMPLAINTS: A CROSS-SECTIONAL STUDY IN CROATIA
}

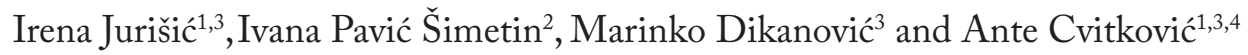 \\ ${ }^{1}$ Institute of Public of Health, Brod-Posavina County, Slavonski Brod, Croatia; \\ ${ }^{2}$ Croatian Institute of Public Health, Zagreb, Croatia; \\ ${ }^{3}$ Faculty of Medicine, Josip Juraj Strossmayer University of Osijek, Osijek, Croatia; \\ ${ }^{4}$ Faculty of Dental Medicine and Health, Josip Juraj Strossmayer University of Osijek, Osijek, Croatia
}

\begin{abstract}
SUMMARY - Headaches are very common in school population. The aim of this study was to determine epidemiological data on headaches among Croatian schoolchildren and their connection to risk factors and other health complaints. In the study, we used the Croatian database of the international research entitled Health Behavior in School-aged Children for 2013/2014. It is a cross-sectional study conducted every four years in 44 countries among children aged 11-16. The students were interviewed using an anonymous standardized questionnaire. The Croatian sample consisted of 5741 students, of which $2857(49.8 \%)$ girls and $2884(50.2 \%)$ boys. The response rate was $85.9 \%$. Headaches were reported to be often (once a week to daily) by $23.5 \%$ of students and were more often in girls and in higher school grades. They were positively linked to cigarette smoking and health complaints such as back pain and stomachache, bad mood, nervousness, irritability, difficulties with sleeping and dizziness. Headaches are associated to many health problems and can cause difficulties in student functioning. This could be a serious problem. This study pointed to connection of headaches with cigarette smoking and importance to underpin the smoking prevention programs.
\end{abstract}

Key words: Headache; Child; Risk factors; Health behavior; Cross-sectional studies; Smoking

\section{Introduction}

Somatic pain is very common among adolescents ${ }^{1}$. Along with stomachache and back pain, headaches are the most common health issue and the most common type of pain in this age group, with an ever-increasing prevalence ${ }^{1-7}$. They are the most often recurring symptom and are connected to pain in adult age ${ }^{1,8,9}$. Headaches are a public health problem with an impact on both the individuals and the society ${ }^{10}$.

According to studies conducted thus far, the prevalence of headache varies considerably ${ }^{3,11,12}$, depending on the formulation of questions related to headaches

Correspondence to: Irena Jurišić, MD, A. Cesarca 71, HR-35000 Slavonski Brod, Croatia

E-mail: irena.jurisic72@gmail.com

Received October 10, 2017, accepted September 24, 2018 in questionnaires and on the age of the respondents (in the literature, 4 to 18 years of age), therefore literature data are not easy to compare. Thus, according to one study, 10\%-30\% of schoolchildren suffer from headaches once a week or once a day and 9\%-33\% at least once a month (age 7-17 years) ${ }^{4}$. Also, the prevalence of headache episodes from once a month to ever in life was $54.4 \%-58.4 \%$, weekly $6 \%-44 \%$, and daily $1 \%-9 \%$ (age $12-18$ years) ${ }^{7}$. Other authors state that $33 \%-40 \%$ of schoolchildren suffer from headaches at least once a week (age 12-15 years) ${ }^{5}$. In Croatia, the prevalence of recurrent headaches was $30.1 \%$ in the population of high school students in Zagreb (age 16-18 years) ${ }^{13}$ and $54.1 \%$ in students from 18 high schools in 10 Croatian cities (age 15-18 years) ${ }^{14}$. Headaches occur more often in girls than in boys and become more frequent with age and level of education ${ }^{1,5,12,15,16}$. Iranian researchers 
found no difference between genders stratified according to age groups ${ }^{12}$.

Headaches decrease the quality of life $\mathrm{f}^{3,7,8,11,17}$, have negative influence on school success ${ }^{3,8}$ and cause school absenteeism ${ }^{12,17}$. They are linked to emotional and physical difficulties ${ }^{4,5,7,8}$. Available research results prove relation with symptoms of depression and anxiety ${ }^{4,8,17,18}$, musculoskeletal pain ${ }^{1,6,8}$, obesity ${ }^{5,8}$, epilepsy and asthma ${ }^{8}$. Headaches represent a multifactorial dis$\operatorname{order}^{8,16,17}$. They are linked to stress, primarily in school (due to tests and questioning), school environment, psychological and physical abuse, peer violence, inadequate spending leisure time and high parental expectations ${ }^{1,3,5,6,11}$. Authors also state that there is connection with alcohol consumption, cigarette smoking, use of electronic media and physical inactivity ${ }^{1,2,5,6,9}$.

The aim of this study was to determine epidemiological data on headaches among Croatian schoolchildren and their connection to risk factors and other health complaints.

\section{Subjects and Methods}

We used the Croatian database from the Health Behavior of School-aged Children (HBSC) for 2013/ 2014, a cross-sectional study supported by the World Health Organization. The principal investigator in Croatia is the Croatian Institute of Public Health. Research methodology is described in detail elsewhere ${ }^{19}$.

The advantages of this research over other researches in the field is the large multinational sample and use of standardized methods to create the database $^{1}$. It is conducted across Europe, North America and Israel every four years and respondents are children aged 11-16. Croatia is one of 44 countries participating in the study. The basic research principle is to monitor, in defined time intervals, the health and behavior among school-aged children and investigate how school, family and other social factors influence the lifestyle and behavior of youth ${ }^{20}$.

\section{Participants}

Our study was conducted in April 2014 among students in our elementary and high schools aged 11, 13 and 15 years. The students were interviewed using an anonymous standardized questionnaire. School and class selection was done by the Croatian Institute of
Public Health using a random sample. Student interviews were conducted anonymously, voluntariness of student participation was secured by providing the student parents/caretakers with the option to decline it without any explanation. The study was approved by the Ministry of Science, Education and Sports and Ethics Committee of the Croatian Institute of Public Health.

The Croatian sample comprised of 5741 students, including 2857 (49.8\%) girls and 2884 (50.2\%) boys. There were 1792 students aged 11 (mean age, 11.6), 2003 students aged 13 (mean age, 13.6) and 1946 students aged 15 (mean age, 14.6). The response rate was $85.9 \%$.

\section{Variables}

The questionnaire consists of 74 questions. One pertains to health complaints whereby the type of investigation is common and represents a reliable measure of psychosomatic difficulties recorded in students ${ }^{21}$.

Health complaints were assessed using a standard list of health complaints by using the following questions: "How often in the past 6 months have you had one of the following: headache, stomachache, back pain, irritability or bad mood, feeling of nervousness, difficulty falling asleep and dizziness"; the multiple choice answers are: $1=$ every day, $2=$ more than once a week, 3 = every week, 4 = every month, and $5=$ rarely or never.

On analysis, the variable of health complaint frequency was dichotomized so that the answers 1, 2 and 3 (often) were compared to answers 4 and 5 (rarely).

Cigarette smoking was assessed by the question: "How often do you smoke cigarettes?" Response options were: 1 = every day, 2 = at least once a week, not every day, 3 = less than once a week, 4 = I don't smoke at all. On analysis, the variable was dichotomized, i.e. answers 1, 2 and 3 versus 4 .

Drunkeness was assessed by the question: "Have you ever had so much alcohol that you were really drunk?", with possible answers: $1=$ no, never, $2=$ yes, once, $3=$ yes, $2-3$ times, $4=$ yes, $4-10$ times, and $5=$ yes, more than 10 times. Answers were dichotomized, i.e. 1 and 2 versus 3,4 and 5 .

We also analyzed distribution and association according to gender and age. 
The study may have suffered from bias due to subjective assessment of respondents used as a measure for headaches and also due to understanding the term headache in schoolchildren (i.e. does every 11-yearold child know what the word headache means).

Statistical analysis of the questionnaires was conducted using IBM SPSS Statistics 23.0 (Base). We used descriptive statistics to determine the frequency and distribution, and binary logistic regression to analyze the association between headaches and cigarette smoking, drunkenness, other health complaints, gender and age.

\section{Results}

Frequent headaches were reported by 431 (15.8\%) boys and 862 (66.7\%) girls (Table 1 ).

Frequent headaches were reported by $21.3 \%$ of girls aged $11,36 \%$ of girls aged 13 and $42.7 \%$ of those aged 15 . In boys, the respective figures were $30.9 \%$, $36.9 \%$ and $32.3 \%$ (Table 2).

Associations between headaches and age, gender, smoking, drunkenness and other health complaints are

Table 1. Headache prevalence according to gender

\begin{tabular}{|c|c|c|c|}
\hline \multirow[b]{2}{*}{$\begin{array}{l}\text { Headache } \\
\text { frequency }\end{array}$} & \multicolumn{2}{|c|}{ Gender } & \multirow[b]{2}{*}{$\begin{array}{l}\text { Total, } \\
\text { N (\%) }\end{array}$} \\
\hline & $\begin{array}{l}\text { Male, } \\
\mathrm{n}(\%)\end{array}$ & $\begin{array}{l}\text { Female, } \\
\mathrm{n}(\%)\end{array}$ & \\
\hline Every day & $93(3.4)$ & $234(8.4)$ & 327 (5.9) \\
\hline $\begin{array}{l}\text { More than } \\
\text { once a week }\end{array}$ & $126(4.6)$ & 283 (10.2) & $409(7.4)$ \\
\hline Every week & $212(7.8)$ & 345 (12.4) & 557 (10.1) \\
\hline Often - total & $431(15.8)$ & $862(31.1)$ & $1293(23.5)$ \\
\hline Every month & $514(18.9)$ & $581(20.9)$ & 1095 (19.9) \\
\hline $\begin{array}{l}\text { Rarely } \\
\text { or never }\end{array}$ & $1776(65.2)$ & $1333(48.0)$ & 3109 (56.6) \\
\hline Rarely - total & $2290(84.2)$ & 1914 (68.9) & $4204(76.5)$ \\
\hline Total & $2721(49.5)$ & $2776(50.5)$ & $5497(100)$ \\
\hline
\end{tabular}

Table 2. Headache frequency according to gender and age

\begin{tabular}{|l|l|l|l|l|}
\hline \multirow{2}{*}{$\begin{array}{l}\text { Age } \\
\text { (yrs }\end{array}$} & \multicolumn{3}{|c|}{ Headache } \\
\cline { 2 - 5 } & \multicolumn{2}{|c|}{ Often } & \multicolumn{2}{c|}{ Rarely } \\
\cline { 2 - 5 } & Male (\%) & Female (\%) & Male (\%) & Female (\%) \\
\hline 11 & 30.9 & 21.3 & 29.8 & 37.9 \\
13 & 36.9 & 36.0 & 34.1 & 35.0 \\
15 & 32.3 & 42.7 & 36.1 & 27.2 \\
\hline
\end{tabular}

Table 3. Multivariate, adjusted binary logistic regression for associations of headache with age, gender, smoking, drunkenness and other health complaints (whole sample)

\begin{tabular}{|l|l|}
\hline & OR, 95\% CI, $\mathrm{p}$ \\
\hline Age & $1.34,1.23-1.46, \mathrm{p}=0.000$ \\
Gender & $2.45,2.15-2.8, \mathrm{p}=0.000$ \\
Smoking & $1.94,1.45-2.59, \mathrm{p}=0.000$ \\
Drunkenness & $1.18,0.81-1.72, \mathrm{p}=0.390$ \\
Stomachache & $3.31,2.66-4.13, \mathrm{p}=0.000$ \\
Back pain & $2.08,1.71-2.54, \mathrm{p}=0.000$ \\
Bad mood & $2.06,1.68-2.53, \mathrm{p}=0.000$ \\
Irritability & $1.39,1.14-1.70, \mathrm{p}=0.001$ \\
Nervousness & $1.57,1.32-1.87, \mathrm{p}=0.000$ \\
Difficulty falling asleep & $1.56,1.27-1.90, \mathrm{p}=0.000$ \\
Dizziness & $4.82,3.72-6.24, \mathrm{p}=0.000$ \\
\hline
\end{tabular}

$\mathrm{OR}=$ odds ratio $95 \% \mathrm{CI}=95 \%$ confidence interval; $\mathrm{p}=$ level of significance

shown in Table 3. Frequent headaches were connected with gender (OR 2.45, CI 2.15-2.8) and age (OR 1.34 , CI 1.23-1.46). They were also connected with cigarette smoking, i.e. students who were smoking cigarettes had more frequent headaches than those who were not smoking (OR 1.94, CI 1.45-2.59).

Students with other health problems had more frequent headaches, including students with stomachache (OR 3.31, CI 2.66-4.13) and back pain (OR 2.08, OR 1.71-2.54).

Students in bad mood had more frequent headaches than those in good mood (OR 2.06, CI 1.682.53). Students with irritability had more frequent headaches than those without it (OR 1.39, CI 1.141.70).

There was also positive connection of frequent headaches with nervousness (OR 1.57, CI 1.32-1.87), difficulty falling asleep (OR 1.56, CI 1.27-1.90), and dizziness (OR 4.82, CI 3.72-6.24).

\section{Discussion}

According to the results of our study, almost every fourth student $(23.5 \%)$ had headaches often; headaches were more frequent in girls, and were associated with age. The study pointed to the connection of headaches and cigarette smoking. Headaches were associated with other concurrent somatic complaints (back pain, stomachache and dizziness) and psychological 
difficulties (bad mood, nervousness, irritability, sleeping difficulties).

Headaches are a subjective experience for which there is no objective measurement instrument. In this study, the prevalence of headaches in schoolchildren in Croatia could not be determined due to the way the questions related to headaches are formulated. There is no answer that would separate the students who have never had headache. For this reason, we can only speak of a higher or lower frequency, i.e. of often or rarely occurring headaches in schoolchildren. The possibility of bias was reduced in a large multinational, representative sample and application of standardized methods by the HBSC researchers ${ }^{6}$. There is a research claiming that children already after 5 years of age are able to understand and use the scales for assessment of the duration and intensity of physical symptoms ${ }^{22}$.

Available literature shows great difference in numerical indicators due to a small number of studies conducted, mainly on small samples investigated and measured using various methods within a broad age range. The age of respondents in our study was 11-15 years versus 4-17 years in the searched and cited literature, which needs to be taken into account when comparing headache frequency. In our study, every fourth student (23.5\%) reported having a headache from every day to every week, which corresponds to literature data (10\%-30\%). Swedish authors report on 6\%-44\% of students having a headache once a week versus $7.4 \%$ of our students ${ }^{2}$. Furthermore, 5.9\% of Swedish students reported having headaches daily, yielding a frequency of $1 \%-9 \%$, as assessed by the authors. Having a headache once a month to ever in life, according to their research, was found in $55.4 \%-58.4 \%$ of students, whereas in our study the percentage of children with the same frequency of headaches was significantly higher (76.5\%).

The research conducted thus far shows that headache is more frequent in girls and increases with age ${ }^{8,11}$. In Croatia, headache is more frequent in girls (about 2.5 times more frequent) with a statistically significant gender difference, and is on increase with age.

Adolescents suffering from headaches are prone to risky behavior such as addictive substance use. In Croatia, headaches are more frequent in students who smoke cigarettes ${ }^{2,3}$.

Health complaints showed association of headaches with irritability or bad mood, nervousness, diffi- culty falling asleep and dizziness. The association was highest with dizziness (students with dizziness had headaches 4 times more often). Students suffering from frequent headaches also had stomachache and back pain more often ( 3 and 2 times, respectively). According to literature data, isolated headaches are an exception rather than a rule and often coexist with other pain ${ }^{8}$.

Pain in childhood is an excellent predictor of suffering pain in adult age. Since there is an association between pain in adult age and adolescence, it is important to know how to act preventively in adolescence ${ }^{6}$. Even though it is not possible to influence some risk factors, many of them are preventable and we can influence the frequency of headaches by changing habits and behaviors.

In conclusion, headaches are common among Croatian students, more common among female students and in older age groups. They are associated with many other health complaints. Their coexistence can cause serious problems in student functioning. Our study also pointed to the association of headaches with cigarette smoking, thus calling for upgrading the smoking prevention programs.

\section{References}

1. Swain MS, Henschke N, Kamper SJ, Gobina I, Ottova-Jordan $\mathrm{V}$, Maher CG. An international survey of pain in adolescents. BMC Public Health 2014;14:447, https://doi.org/10.1186/1471-2458-14-447.

2. Milde-Busch A, von Kries R, Thomas S, Heinrich S, Straube A, Radon K. The association between use of electronic media and prevalence of headache in adolescents: results from populationbased cross-sectional study. BMC Neurology. 2010;10:12, https://doi.org/10.1186/1471-2377-10-12.

3. Mehta S. Study of various social and demographic variables associated with primary headache disorder in 500 school going children in central India. J Pediatr Neurosci. 2015;10(1):13-7.

4. Lee SM, Yoon JR, Yi YY, Eom S, Lee JS, Kim HD, et al. Screening for depression and anxiety disorder in children with headache. Korean J Pediatr. 2015;58(2):64-8, https://doi. org/10.3345/kjp.2015.58.2.64.

5. Straube A, Heinen F, Ebinger F, von Kries R. Headache in school children: prevalence and risk factors. Dtsch Arztebl Int. 2013;110(48):811-8, https://dx.doi.org/10.3238\%2Farztebl.2013.0811.

6. Milde-Busch A, Straube A, Heinen F, von Kries R. Identified risk factors and adolescents' beliefs about triggers for headache: results from a cross-sectional study. J Headache Pain. 2012; 13:639-43, https://doi.org/10.1007/s10194-012-0489-7. 
7. Larsson B, Fichtel A. Headache prevalence and characteristics among adolescents in the general population: a comparison between retrospect questionnaire and prospective paper diary data. J Headache Pain. 2014;15(1):80, https://doi.org/10.1186/1129-2377-15-80.

8. Dyb G, Stensland S, Zwart JA. Psychiatric comorbidity in childhood and adolescence headache. Curr Pain Headache Rep. 2015;19(3):5, https://doi.org/10.1007/s11916-015-0479-y.

9. Botello-Harbaum M, Haynie DL, Murray KW, Iannotti RJ. Cigarette smoking status and recurrent subjective health complaints among United States school-aged adolescents. Child Care Health Dev. 2011;37(4):551-8, https://doi.org/10.1111/ j.1365-2214.2010.01147.x.

10. Vuković Cvetković V, Bašić Kes V, Šerić V, Vargek Solter V, Demarin V, Jančuljak D, et al. Evidence based guidelines for treatment of primary headaches -2012 update. Acta Clin Croat. 2012;51:323-78.

11. Castro K, Rocket FC, Billo M, Oliveira GT, Klein LS, Parizotti CS, et al. Lifestyle, quality of life, nutritional status and headache in school-aged children. Nutr Hosp. 2013;28(5):1546-51, https://doi.org/10.3305/nh.2013.28.5.6729.

12. Tavasoli A, Aghamohammadpoor M, Taghibeigi M. Migraine and tension-type headache in children and adolescents presenting to neurology clinics. Iran J Pediatr. 2013;23(5):536-40.

13. Cvetković Vuković V, Plavec D, Lovrenčić-Huzjan A, Strineka $\mathrm{M}, \mathrm{Ažman} \mathrm{D}$, Bene R. Prevalence and clinical characteristics of headache in adolescents: a Croatian epidemiology study. Cephalalgia. 2014;34(4):289-97, https://doi.org/10.1177/0333102413507636.

14. Sedlic M, Mahovic D, Kruzliak P. Epidemiology of primary headaches among 1,876 adolescents: a cross-sectional survey. Pain Med. 2015;17(2):353-9, https://doi.org/10.1093/pm/pnv033.
15. Lehmann S, Milde-Busch A, Straube A, von Kries R, Heinen F. How specific are risk factors for headache in adolescents? Results from a cross-sectional study in Germany. Neuropediatrics. 2013;44(1):46-54, https://doi.org/10.1055/s-0032-1333432.

16. Albers L, von Kries R, Heinen F, Straube A. Headache in school children: is the prevalence increasing? Curr Pain Headache Rep. 2015;19(3):4, https://doi.org/10.1007/s11916-0150477-0.

17. Rousseau-Salvador C, Amouroux R, Annequin D, Salvador A, Tourniaire B, Rusinek S. Anxiety, depression and school absenteeism in youth with chronic or episodic headache. Pain Res Manag. 2014;19(5):135-40.

18. Blaauw BA, Dyb G, Hagen K, Holmen TL, Linde M, Wentzel-Larsen T, et al. Anxiety, depression and behavioral problems among adolescents with recurrent headache: the YoungHUNT study. J Headache Pain. 2014;15(1):38, https://doi. org/10.1186/1129-2377-15-38.

19. Currie C, Inchley J, Molcho M, Lenzi M, Veselska Z, Wild F, editors. Health Behaviour in School-Aged Children (HBSC) study protocol: background, methodology and mandatory items for the 2013/14 survey. St Andrews: Child and Adolescent Health Research Unit, University of St Andrews; 2014. Available from: http://www.hbsc.org/news/index.aspx? ni=2418. Accessed 26 February 2017.

20. Kuzman M, Pavić-Šimetin I, Pejnović-Franelić I. Ponašanje u vezi sa zdravljem u djece školske dobi 2009/2010 (Health behavior in school-aged children 2009/2010). Zagreb: Croatian Institute of Public Health, 2012. (in Croatian)

21. Pavić-Šimetin I. Pupils' subjective health and socioeconomic surrounding (dissertation). Zagreb: University of Zagreb, 2011.

22. Vulić-Prtorić A. Psychosomatic symptoms questionnaire for children and adolescents. Suvrem Psihol. 2005;8:211-7.

Sažetak

\section{GLAVOBOLJE KOD ADOLESCENATA - UČESTALOST, RIZIČNI ČIMBENICI I DRUGE ZDRAVSTVENE POTEŠKOĆE: HRVATSKO PRESJEČNO ISTRAŽIVANJE}

\section{Jurišić, I. Pavic Šimetin, M. Dikanović i A. Cvitković}

Glavobolje su vrlo česte kod školske djece. Cilj ovoga rada bio je utvrditi epidemiološke karakteristike glavobolja kod školske djece i njihovu povezanost s rizičnim čimbenicima i drugim zdravstvenim tegobama. Koristili smo hrvatsku bazu podataka međunarodnog istraživanja Health Behavior in School-aged Children za 2013./2014. godinu. To je presječno istraživanje koje se provodi svake četiri godine u 44 zemlje, a uključuje školsku djecu u dobi od 11 do 16 godina. Učenici se ispituju standardiziranim, anonimnim upitnikom. Uzorkom je u Hrvatskoj obuhvaćeno 5741 učenika, od kojih je bilo 49,8\% učenica ( $n=2857)$ i 50,2\% učenika ( $n=2884)$, uz odziv od $85,9 \%$. Glavobolje je imalo često (od jednom tjedno do svakodnevno) $23,5 \%$ učenika i to češće kod učenica u višim razredima. Utvrđena je pozitivna povezanost s pušenjem cigareta i drugim zdravstvenim tegobama poput bolova u leđima i trbuhu te lošim raspoloženjem, nervozom, iritabilnosti, poteškoćama spavanja i vrtoglavicama. Glavobolje su povezane s mnogim zdravstvenim tegobama i mogu utjecati na funkcioniranje učenika, što može biti ozbiljan problem. Ovaj rad je ukazao na povezanost glavobolja i pušenja cigareta te na važnost jačanja preventivnih programa u tu svrhu.

Ključne riječi: Glavobolja; Dijete; Rizični čmbenici; Zdravstveno ponašanje; Presječno istraživanje; Pušenje 